\title{
An Acquired Taste: Emulation and Indigenization of Cattle Forelimbs in the Southern Levant
}

\author{
Adam Allentuck
}

\begin{abstract}
The influence of Egyptian unification and expansion on the southern Levant at the end fourth millennium $\mathbf{B C}$ has been the source of a protracted debate. In this article, a novel approach to the study of Egyptian-Levantine relations considers how food preferences, mediated by knowledge transmission and local cultural logic, provide an effective interpretive scheme for understanding the nature of relations between neighbouring societies. To this end, zooarchaeology can reveal how food preferences become enmeshed into the transformation of identity. Zooarchaeological analysis from the Early Bronze I (EB I) village of Horvat 'Illin Tahtit, Israel, finds a clear overrepresentation of cattle forelimb parts relative to hindlimb parts. The results of a correspondence analysis of faunal data from late fourth-/ early third-millennium assemblages in the Levant and Egypt shows that this pattern of forelimb overrepresentation is most common in Late EB I when the intensity of EgyptianLevantine relations peaked. I suggest that while Egyptians clearly accorded high status to cattle forelimbs, their Levantine contemporaries, who did not have materially inscribed social rankings, defined cattle forelimbs according to a cultural logic unrelated to status.
\end{abstract}

The influence of Egyptian unification and expansion on the southern Levant at the end of the fourth and beginning of the third millennia $\mathrm{BC}$ has been the source of protracted debate. The southern Levant was engaged in exchange relations with people living along the Nile on the eve of the unification of Lower and Upper Egypt around 3100 вс. The intensity of these interactions reached its apogee at the end of the Early Bronze (EB) I period and was focused on southern Israel. Increasing Egyptian demand for Levantine wine and possibly olive oil galvanized trade relations that began in the Late Chalcolithic period.

Studies of Egypt's impact on the southern Levant during the Early Bronze Age (EBA) have focused on definitions of their political economic relationship. There is a general consensus that Egypt from Naqada II through Old Kingdom (3500-2125 BC) and the southern Levant from Late Chalcolithic through EB III (c. 3800-2500 вС) established intermittent partnerships for the purpose of economic exchange (Table 1). However, the shifting balance of power between a colo- nial authority and indigenous settlements is still an open question. Interlocutors in this debate have made valuable contributions toward addressing problems of chronological synchronism, media of exchange, changes between overland and maritime trade routes, intensity of trade, and centralization of Egyptian administration. However, the models that have emerged from this debate have reduced a complex historical narrative to dichotomous positions of colonial vs reciprocal exchange and Egyptian autocracy vs Levantine autonomy.

A critical issue in studies of interregional interaction and one that has the potential to provide a more nuanced understanding of Egyptian-Levantine relations is the transformation of social identity. The ways in which the production and consumption of Egyptian-style material culture became enmeshed in the reproduction of Levantine community identity have received little scholarly attention. Kansa (2001, 109-13) provides a notable exception that underscores the fluidity and flexibility of Egyptian-Levantine

Cambridge Archaeological Journal 25:1, 45-62 $\quad$ C 2015 McDonald Institute for Archaeological Research. The online version of this article is published within an Open Access environment subject to the conditions of the Creative Commons Attribution licence http://creativecommons.org/licenses/by/3.0/ doi:10.1017/S0959774314000249 Received 21 Dec 2013; Accepted 18 Feb 2014; Revised 27 Feb 2014 
Adam Allentuck

Table 1. Southern Levantine-Egyptian chronological synchronisms (based on Braun \& van den Brink 2008, table 1) with revised chronometric dates (Regev et al. 2012). Egyptian sites are italicized.

\begin{tabular}{|c|c|c|c|c|}
\hline Levantine period & Dates (вC) & $\begin{array}{l}\text { Sites mentioned in } \\
\text { text }\end{array}$ & \multicolumn{2}{|c|}{ Egyptian period } \\
\hline Late Chalcolithic & Early 4 th millennium & El-Mahâsnah & & $\begin{array}{l}\text { Naqada IA-C } \\
\text { Naqada IIA/B }\end{array}$ \\
\hline Early EB I & c. $3600-3150$ & $\begin{array}{l}\text { Azor } \\
\text { En Shadud } \\
\text { Nahal Tillah (IIIB/C) } \\
\text { Yiftah'el (II) } \\
\text { Hierakonpolis }\end{array}$ & \multirow[t]{2}{*}{ Late Predynastic } & $\begin{array}{l}\text { Naqada IIC-D1 } \\
\text { Naqada IID2-IIIA1 }\end{array}$ \\
\hline Late EB I (Erani C) & c. $3150-3100$ & $\begin{array}{l}\text { Qiryat Ata (III) } \\
\text { T. Erani (C, D) } \\
\text { Hartuv } \\
\text { Nahal Tillah (IIIA) }\end{array}$ & & $\begin{array}{l}\text { Naqada } \\
\text { IIIA1-IIIA2 }\end{array}$ \\
\hline $\begin{array}{l}\text { Late EB I } \\
\text { (Advanced EB I) }\end{array}$ & c. $3100-3000$ & $\begin{array}{l}\text { Qiryat Ata (II) } \\
\text { Lod } \\
\text { Tel Dalit } \\
\text { HIT (III, IV) } \\
\text { 'En Besor (III) } \\
\text { Nahal Tillah (IIA/B) } \\
\text { Arad (IV) } \\
\text { Tell es-Sakan (Area A) } \\
\text { Abydos }\end{array}$ & \multirow[t]{2}{*}{ Early Dynastic } & $\begin{array}{l}\text { Naqada IIIB-C1/ } \\
\text { Dynasty } 0\end{array}$ \\
\hline EB II & c. $3000-2900$ & $\begin{array}{l}\text { Me'ona } \\
\text { Qiryat Ata (I) } \\
\text { Aphek (Area A/B) } \\
\text { Arad (III) } \\
\text { Tel Yarmut }\end{array}$ & & $\begin{array}{l}\text { Naqada IIIC1/ } \\
\text { Dynasty } 1\end{array}$ \\
\hline EB III & c. $2900-2500$ & $\begin{array}{l}\text { Tel Yarmut } \\
\text { Tell es-Sakan (Area B, } \\
\text { C) } \\
\text { Saqqara }\end{array}$ & $\begin{array}{l}\text { Early Dynastic/ } \\
\text { Old Kingdom }\end{array}$ & Dynasty $2-4$ \\
\hline EB IV / IBA & c. $2500-2000$ & Giza & Old Kingdom & Dynasty 5-11 \\
\hline
\end{tabular}

social boundaries in an assessment of the relationship between pottery style and ethnic identity. Indeed, research in the southern Levant from the Neolithic onward traditionally looked to ceramic style over all other material residues when drawing inferences of social distinctions. In Egyptian-Levantine interaction research, food residues, such as faunal and botanical remains, have been largely neglected despite their potential to identify social boundaries. Food in general and meat in particular are used to signal aspiration to group affiliation (Fiddes 1991, 33-4; Twiss 2007, 3). To procure, share and consume meat is to affirm the shared values of a social group and perform acts of commensality. Likewise, deviations from the dietary preferences of the dominant culture may be used to express dissent and resistance (Douglas 2002 [1966], 60).

\section{Aims and objectives}

In this article, I examine issues of food-preference emulation in relation to culture contact and ethnicity. Following a brief synopsis of Egyptian-southern Levantine relations, the article offers zooarchaeological evidence in support of a theory for transformations of social identity impelled by late fourth- and early thirdmillennium foreign relations. Zooarchaeological analysis is presented at two scales. First, cattle forelimb preference at a single site, Horvat 'Illin Tahtit, is assessed through skeletal part frequency data. Detailed analyses of these data in terms of skeletal-part profiles, evenness, density-mediated attrition and food utility are submitted in order to understand cattlecarcass portioning within a community. Second, cattle skeletal-part frequencies compiled from published and unpublished sources are used to gain an understanding of regional patterns of cattle-carcass portioning. To this end, correspondence analysis is used to assess the similarities and differences among cattle skeletal-part assemblages. Chronological association, locational proximity to Egypt, and the extent to which the material culture assemblages are Egyptian in character are factors used to constrain interpretations of regional patterning from the correspondence analysis. This article presents arguments and evidence in support of the hypothesis that Horvat 'Illin Tahtit and several other Early Bronze Age communities in 


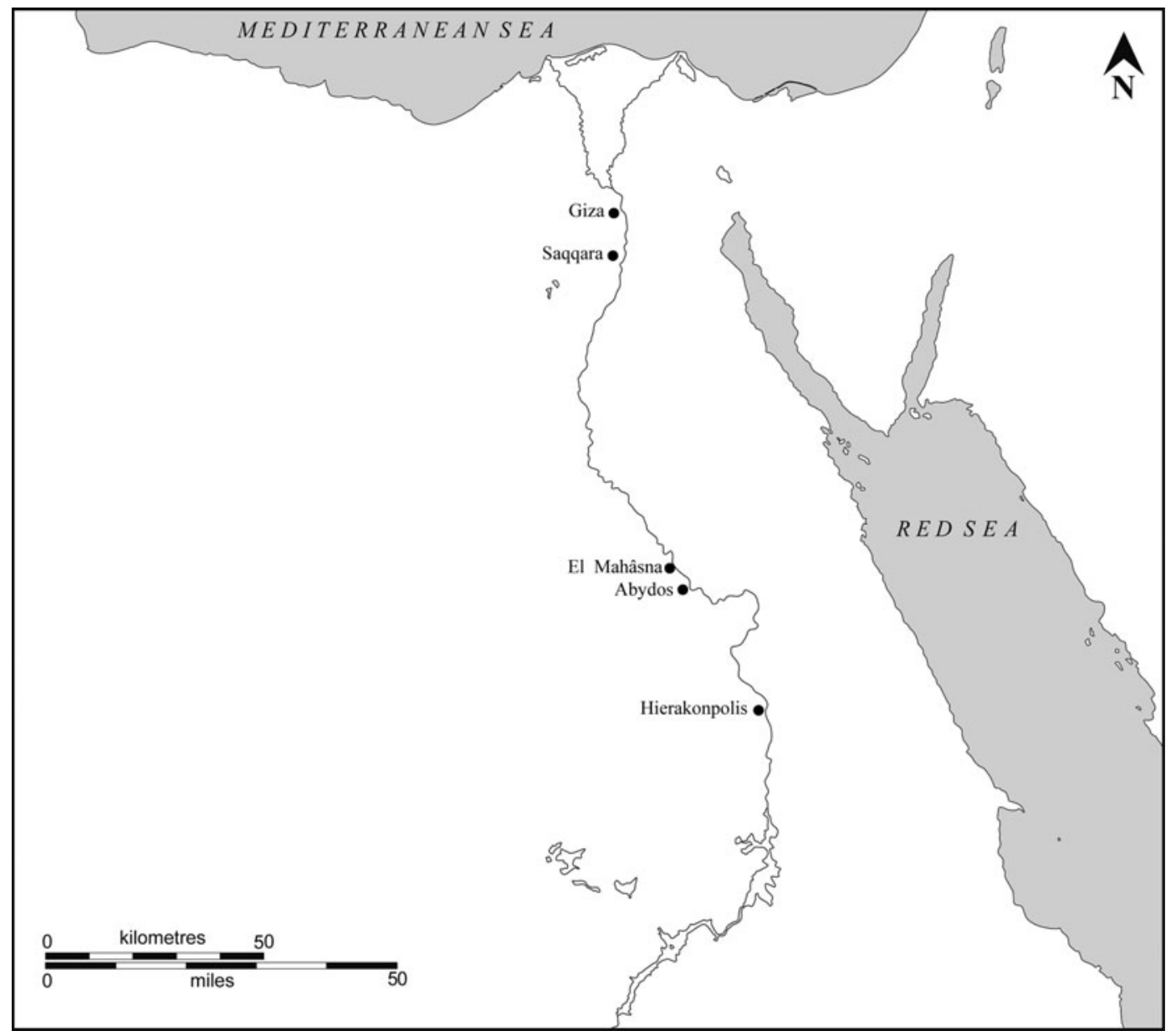

Figure 1. Map of Egypt showing sites mentioned in the text.

the southern Levant developed hybridized identities through repeated encounters with Egyptian ideas and material culture. In the conclusion, I draw together connections among culture contact, identity formation and food preference that I argue can account for an apparent food preference for cattle forelimbs.

\section{Background to southern Levantine-Egyptian relations in the late fourth to mid-third millennium}

The study area

The periodic Egyptian presence in the southern Levant over the course of the late fourth to mid-third millennium reached its height during the latest phase of Late EB I (c. 3150-3000 вC). Intermittent contact is also apparent in the antecedent Late Chalcolithic and Early EB I periods and in the subsequent EB II-III phases, but relations between these two regions were more ephemeral in these periods than in Late EB I. At the end of the fourth millennium $\mathrm{BC}$, the Nile valley was on the path to state formation through the po- litical unification of Upper and Lower Egypt (Fig. 1). Large cemeteries developed and material culture became standardized up and down the Nile from Late Naqada II through Naqada III (Baines \& Yoffee 1998). This nascent territorial state controlled a vast expanse from Aswan in the south to the Mediterranean coast in the north. The early Egyptian state also maintained exchange relations with its neighbours to the south (Nubia) and north (southern and northern Levant). The consolidated state was founded on extreme disparities of wealth and status, which is apparent from lavish funerary customs and mortuary architecture that were reserved for the elite. Evidence for social inequality is apparent as early as the Late Predynastic period (Naqada IIc period, c. 3300 BC) in Tomb 100 at Hierakonpolis. This tomb contains a wall painting that depicts several themes that became common throughout the Pharaonic period, including a violent ruler smiting his captives with a mace and the sacrifice of a bull (Kemp 2006, 81; Quibell \& Green 1902, pl. LXXV). 


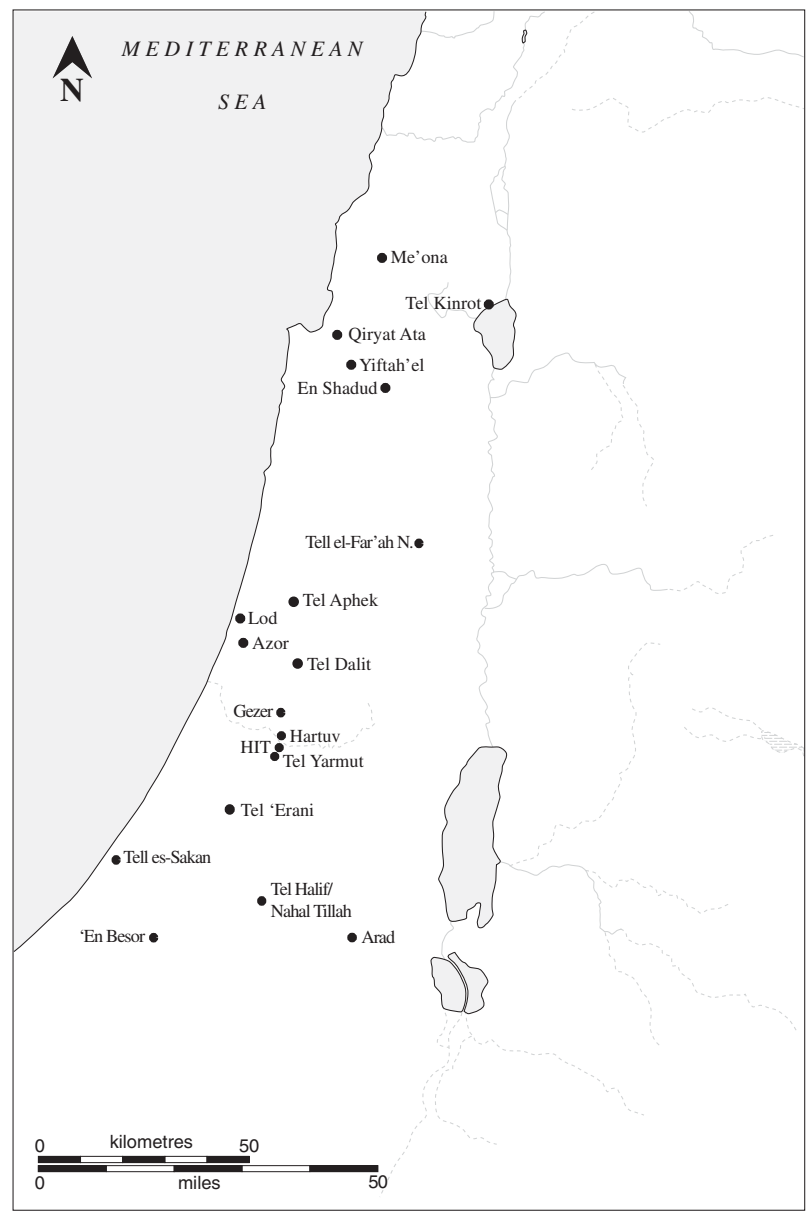

Figure 2. Map of the southern Levant showing sites mentioned in the text.

The southern Levant was a mosaic of small-scale regionalized factions (Fig. 2). Although this regionalism of the southern Levant produced a dispersed political landscape, it also produced a variety of new or expanded economic resources that included the deployment of the donkey for long-distance trade; intensified olive and grape horticulture in response to an Egyptian demand; expanded copper mining at Feinan; and expanded contacts with the northern Levant (Lebanon), the east (including Jordan) and the south (Negev and Sinai) (de Miroschedji 2002, 40). These conditions in the southern Levant set the stage for exchange relations with the burgeoning Egyptian state. The imprint of Egypt in the southern Levant during Late EB I was such that Egyptians established a colony at Tell es-Sakan and an entrepôt at 'En Besor (Gophna 1995; de Miroschedji et al. 2001). Administrative technology in the form of clay bullae from 'En Besor and Nahal Tillah and a cylinder seal from Gezer reflect a mode of exchange that was highly organized and systematically managed (Braun 2011, 112-13).

While exotic artefacts of complex Egyptian institutions receive much attention (Baines \& Yoffee 1998), the more common goods of exchange provide a clearer understanding of foreign relations. Levantine goods found in Egypt predominantly include staple commodities, such as grape and olive products in Canaanite storage jars and Dead Sea bitumen, while Egyptian goods found in the southern Levant mainly include manufactured items, such as finely made bottles, pearshaped mace-heads, ripple-flaked knives and stone palettes (Brandl 1992; Connan et al. 1992; Harrison 1993; McGovern et al. 1997). This distribution suggests that interregional trade was not necessarily symmetrical (Stager 2001), but was reciprocal.

Most Late EB I sites in the southern Levant, including the site that is the focus of this article, Horvat 'Illin Tahtit (hereafter, HIT and discussed below), display only modest quantities of Egyptian or Egyptianinspired artefact assemblages. A few sites, however, have produced material assemblages substantially composed of Egyptian artefacts. For instance, large quantities of Egyptian bread moulds, other Egyptian pottery (made of local and Egyptian clays), an Egyptian amulet and several clay seal impressions were recovered from Nahal Tillah in the northern Negev desert (Levy et al. 1997). The considerable Egyptian material assemblages at Nahal Tillah were initially thought to reflect evidence for a socially bounded Egyptian enclave in the southern Levant (Levy et al. 1997, 45). However, spatial analysis of the ceramic and faunal data from Nahal Tillah has not found any evidence for ethnic boundaries in the distribution of the food remains and pottery (Kansa et al. 2006). Rather, analysis showed that Egyptian-style pottery was patchily dispersed across the site and spatially overlapped with Levantine-style pottery. While Levy et al. (1997) had previously modelled Egyptians as a dominating colonial presence at Nahal Tillah, Kansa et al.'s (2006) reappraisal drew the opposing conclusion that Egyptians were integrated into the local Levantine economy.

This very brief review of foreign relations underscores the point that Egypt's influence was variable across the southern Levantine landscape. Braun's (2003) synthetic review of Egypt's influence in the southern Levant found that settlements such as Tell es-Sakan and 'En Besor (Stratum III) were under direct Egyptian control and inhabited by ethnic Egyptians. However, the extent of Egypt's control at all other southern Levantine settlements is variable. For instance, substantial quantities of Egyptian and Egyptianized pottery at Tel Erani and Lod signal a 
strong Egyptian presence in a community inhabited by Levantine people. In contrast, sites such as HIT, Arad (Stratum IV), Tel Dalit and Tel Aphek contain only small quantities of artefacts of foreign origin, an indication of a minor degree of Egyptian influence. The variable extent of the long-distance relationships between Egypt and the Levant, and particularly the intermittency of Late Predynastic Egyptian migrations, suggest that the southern Levant comprised a number of pluralistic settlements. It is at these ethnically varied settlements where multiple cultural practices and diverse identities could produce hybridity.

\section{Horvat ‘llin Tahtit (HIT)}

HIT is situated in the central Shephelah immediately west of the Judean anticline. It overlooks Wadi 'Illin (Nahal Shemesh) to the south, a shallow depression that carries runoff from the surrounding hills $1.2 \mathrm{~km}$ west to the Soreq Basin. Excavations revealed two superimposed strata dated by pottery finds to successive occupations associated with an advanced phase of Late EB I (Braun et al. 2001). In revealing approximately $1100 \mathrm{~m}^{2}$ of deposits, the excavators exposed about 20 per cent of an unfortified village estimated to have been no more than 1 ha in area. Stratum IV, which contained remains of the earlier Late EB I sub-phase, was fortuitously preserved by an all-consuming conflagration. The fire was so intense and sustained that mud-brick and plaster installations were completely baked in certain parts of the site. Excavators revealed walls of considerable height and household artefacts abandoned at the time of the destructive fire (Braun 1996, 73). Stratum IV produced a faunal collection of 781 bones and teeth.

The architecture of the succeeding occupation in Stratum III was built directly over the earlier burnt structures, without an apparent hiatus. When Stratum III was abandoned at the end of Late EB I or at the beginning of EB II, many small, intact artefacts found on floors suggest that the process of departure was similarly rapid to that of Stratum IV, but was not motivated by fire (Braun et al. 2001). Its relatively undisturbed condition is attributed to the fact that Stratum II (post-EB I) did not apparently intrude into Stratum III. These site-formation processes produced a well-preserved faunal assemblage $(n=1481)$ in Stratum III.

A total of 25 pottery sherds of Egyptian origin were recovered from HIT. This material is differentiated from the local wares by its highly levigated and high-fired, sometimes burnished fabrics, which are typically dark red or brown in colour.
The small proportion of Egyptian pottery as well as a partially preserved serekh incised on the upper portion of a storage jar, another partially preserved serekh incised on a sherd of Nilotic clay, a piriform mace-head made of Egyptian calcite and an Egyptian flint knife suggest minimal but unambiguous contact with Egypt. In addition, a small quantity of Egyptian-inspired pottery of local clay and a palette made on local limestone were recovered (Braun et al. 2001, 74-8). These 'Egyptianized' artefacts are of definite Egyptian morphology, but produced on locallysourced raw materials. Thus, a small quantity of Egyptian artefacts and a smaller quantity of Egyptianized artefacts indicates that these 'are exotic elements in an otherwise local phenomenon' (Braun et al. 2001, 82).

The artefact assemblages from HIT suggest that Egypt was only a peripheral influence. The minor Egyptian component in the material assemblages may reflect the acquisition of foreign goods and knowledge by down-the-line trade with Egyptian-controlled outposts such as Tell es-Sakan and 'En Besor in direct exchange relations with Levantine people at places such as Lod and Tel Erani. Thus, when considering humananimal interactions at HIT, it is reasonable to regard its inhabitants as ethnically Levantine, but likely aware of Egyptian attitudes toward and strategies of animal exploitation.

The HIT faunal collection from Strata III and IV deposits, as well as deposits that could not be confidently attributed to one of these two EB I strata, is composed of 5553 bone and tooth fragments. Of these remains 75 per cent $(n=4164)$ are identified to at least a taxonomic class and size category (i.e. small, medium, large Mammalia). Of these, 1962 specimens are identified to at least a taxonomic family (e.g. Bovidae, Cervidae, Equidae) and size category (NISP or Number of Identified Specimens per Taxon). Sheep and goat specimens are the most abundant category of faunal remains in the assemblage, as they account for 64 per cent $(n=1255)$ of NISP. Its abundance in the death assemblage, notwithstanding taphonomic attrition, should be regarded as an expression of its importance in herding and exploitation practices. Cattle (Bos taurus) account for 20 per cent $(n=392)$ of the identified faunal remains. Pig (Sus scrofa) is the least abundant animal of the major domestic taxa, accounting for about 10 per cent $(n=204)$ of NISP. All other taxa, including equids (Equus sp.), deer (Capreolus capreolus, Dama mesopotamica), gazelle (Gazella sp.), canid (Canis sp.), brown bear (Ursus arctos) and birds (Phasianidae, Buteo sp., Struthio camelus) are only marginally represented ( $<2$ per cent, each) (Allentuck 2013). 


\section{Methods}

Two fundamental methods are used to quantify skeletal part frequencies. First, NISP is a direct method of tallying identified specimens. However, although additive and often appropriate for ordinal-scale statistics, it suffers from the potential pitfall of specimen interdependence. In spite of this problem, it is the quantification method best suited to analyses that attempt to draw inter-site comparisons of a single animal taxon because it does not require the analyst to make decisions about the level of sample aggregation to use.

Second, the diagnostic zone (DZ) method of recording fragmentary animal remains was used for intra-site analyses on the HIT faunal collection. Diagnostic zones were recorded according to modified skeletal element templates of Dobney and Rielly (1988). This technique divides each skeletal element into zones according to diagnostic features and the line along which an element tends to fracture. It is critical to ensure that a bone cannot be counted more than once with any single zone. In order to achieve this, a zone is recorded only if more than 50 per cent of that zone is preserved. Tallying for diagnostic zones obviates the problem of comparing skeletal-part frequencies between taxa with different numbers of anatomical elements because every mammalian species is accorded the same diagnostic zone templates. This is achieved with two procedures. First, skulls and teeth, horn cores, antlers, peripheral metapodials, clavicles and other skeletal elements only found in some mammalian skeletons are omitted. Second, tallies of skeletal elements that occur in varying quantities among taxa, such as metapodia and phalanges, are corrected. Vertebrae and ribs, although universally possessed, are excluded from DZ tallies because most fragmentary specimens are too difficult to identify.

A common use of DZ data is for the derivation of MNE (Minimum Number of Elements) frequencies. MNE is the minimum number of a particular skeletal element necessary to account for an assemblage of specimens of a particular skeletal element, part or portion (Lyman 2008, 220). MNE was calculated according to the procedure outlined in Watson (1979). Long bone epiphyses and shafts were considered in MNE tallies (Pickering et al. 2003; cf. Stiner 2002).

An improved means of discerning patterns of skeletal-part preservation is to compare observed skeletal-part frequencies to the number of skeletons expected based on the most frequent skeletal part for a given taxon. This is achieved by dividing MNE values for each skeletal element by the number of times that skeletal element occurs in a model skeleton. This calculation produces the minimum animal units (MAU) (Binford 1978, 69). MAU is further standardized by dividing all MAU values by the greatest MAU value and multiplying each resultant value by 100 . This last step allows MAU values to be expressed on a scale that approximates a percentage, which is why this scale is often termed \%MAU.

Each analyst confronted with the task of deriving MNE must make these decisions and the fact that the outcomes of these decisions are variable is a strong justification for restricting its use to intra-site (or at best intra-analyst) comparisons. Therefore, MNE and its derivative, MAU, are only used to find patterns of cattle skeletal parts at HIT. When faunal data from HIT are compared to data from other sites in the southern Levant and from sites in Egypt, the simplest, leastderived method of estimating skeletal-part frequency is most appropriate for a conducting a comparative analysis among faunal assemblages and that method is NISP.

Correspondence analysis (CA) was chosen as the statistic through which to assess inter-site cattle skeletal-part frequency patterning because of its capacity to reduce variability into a small number of dimensions. A full description of the statistical basis of CA is not presented here, as it has been detailed in numerous other publications (Bølviken et al. 1982; Shennan 1988; Ter Braak 1986). Suffice it to say that CA is a multivariate statistical method that employs a process of ordination to arrange samples along axes based on their combined compositions. CA is particularly appropriate for the research problem at hand, as the two-dimensional graphical output can display row (assemblage) and column (anatomical part) data in a single plot. The first two dimensions account for the most variation and if together they account for a sufficient proportion of the total variation, they are regarded as proxies for the underlying causes of variation.

The anatomical regions profiling technique is used to circumvent inconsistencies among skeletalelement data reporting and inter-skeletal densitymediated attrition. The anatomical regions profiling technique is ideally suited to inter-assemblage comparisons from which only robust differences in skeletal part patterns are sought (Stiner 2002,981). Anatomical regions each comprise a pooled set of articulating elements from a broad section of the carcass. Skeletalpart data were categorized according to one of four anatomical regions (head, forelimb, hindlimb, foot), a classification based on the definitions of Horwitz and Tchernov (1989, table 5) (Table 2). However, while compiling data from published and unpublished 
Table 2. Anatomical regions based on definitions of Horwitz and Tchernov (1989, table 5), with all the trunk region (vertebrae and ribs) and some elements of the head region (skull fragments, maxilla and loose teeth) omitted.

\begin{tabular}{|l|l|}
\hline Anatomical region & Skeletal elements \\
\hline Head & horncore/antler, mandible \\
\hline Forelimb & scapula, humerus, radius, ulna, carpals, metacarpal \\
\hline Hindlimb & pelvis, femur, tibia, astragalus, calcaneus, tarsals, metatarsals \\
\hline Foot & phalanx I, phalanx II, phalanx III \\
\hline
\end{tabular}

sources it became apparent that analysts selectively record elements of the head region (horn, skull, mandible and loose teeth). In response to this interanalyst variability, the decision was made to omit the head region from the $\mathrm{CA}$ in order to avoid a spurious comparison of incommensurable data. The anatomical regions technique is particularly advantageous because the coarse divisions of the carcass are similar to ancient Egyptian butchering units known from tomb offerings (Ikram 1995). Furthermore, data from publications that report skeletal-part frequencies at this coarse scale of resolution become compatible with data published at finer scales of resolution when skeletal element data of the latter type are amalgamated into multi-element skeletal region data. ${ }^{1}$

Amalgamating individual skeletal elements into multi-element butchery units also presents a statistical advantage when performing CA. Some skeletal element types, by virtue of their size or density, are rarely identified and therefore have small or zero values. Meaningful patterning may be obscured when rare skeletal elements comprise data in a CA plot. In these cases, pooling elements, so long as they are archaeologically meaningful, yields larger column totals. This renders the variables more robust for the chi-square statistic on which CA is based (Baxter \& Cool 2010, 220).

An inevitable consequence of bringing together diverse zooarchaeological data sets into a single analysis is the injection of bias when comparing data with different sample sizes and produced by dissimilar taphonomic processes and recovery strategies. These and other such issues are important to consider when interpreting statistical results, but are not so threatening to the integrity of CA that any particular assemblage should be omitted. Another caveat to consider is a bias against assemblages for which cattle skeletal-part data are not published. This is the reason for which the analysis includes few assemblages from Egypt and none from Jordan. Representation of Egyptian assemblages is further hampered because of a historical focus on tombs rather than settlements.

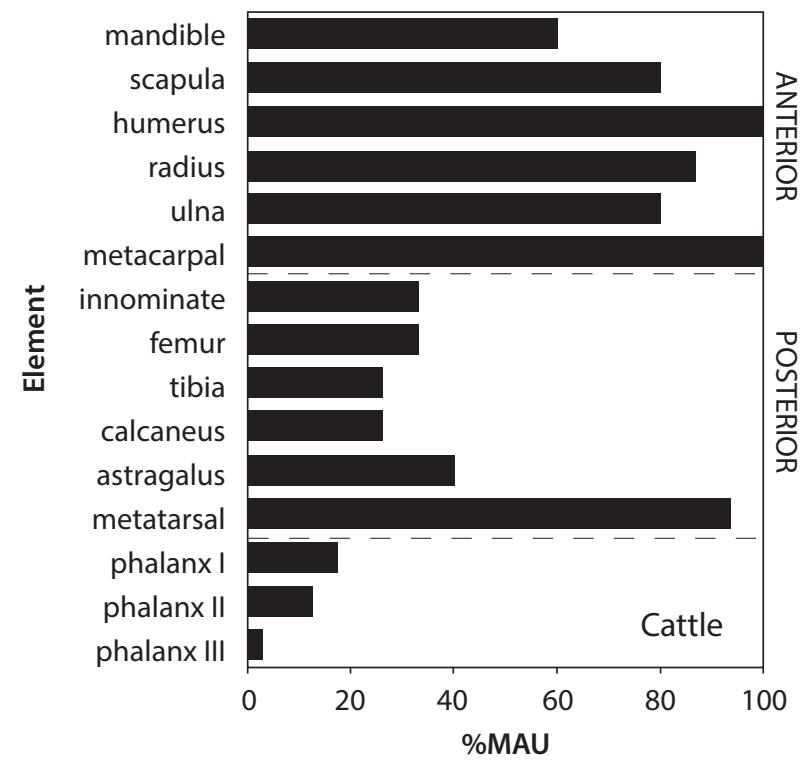

Figure 3. \%MAU values for cattle from HIT.

\section{Results}

Cattle skeletal-part frequencies at HIT

Cattle meat was consumed according to a particularly striking pattern that is found in the distribution of carcass parts. The anterior half of the carcass is overrepresented relative to posterior half. In particular, forelimb elements are considerably more numerous than hindlimb elements. The exception to this pattern is the well-represented metatarsal. A focus on the anterior half of the cattle carcass is also evident from the anatomical distribution of filleting cut-marks that are concentrated on the scapula, humerus and radius.

The skeletal element profile of cattle displays a relatively complete array of elements (Fig. 3). The distal shafts (Zone 8) of the humerus and metacarpal are tied as the most common skeletal parts, and the distal metatarsal, proximal radius, proximal ulna and distal scapula, all of which are structurally robust, are also well represented (Table 3). The tibia, calcaneus and phalanx are among the markedly underrepresented 
Adam Allentuck

Table 3. DZ counts, maximum MNE values, MAU and \%MAU frequencies of cattle from HIT.

\begin{tabular}{|l|l|l|l|l|l|l|l|l|l|l|l|l|l|l|l|}
\hline & \multicolumn{7}{|c|}{ Diagnostic zone } & & & \\
\hline Element & $\mathbf{1}$ & $\mathbf{2}$ & $\mathbf{3}$ & $\mathbf{4}$ & $\mathbf{5}$ & $\mathbf{6}$ & $\mathbf{7}$ & $\mathbf{8}$ & $\mathbf{9}$ & $\mathbf{1 0}$ & $\mathbf{1 1}$ & $\mathbf{1 2}$ & MNEmax & MAU & \%MAU \\
\hline mandible & 9 & 8 & 6 & 4 & 5 & 6 & 4 & & & & & & 9 & 4.5 & 60 \\
\hline scapula & 10 & 10 & 10 & 12 & 12 & 2 & 4 & 1 & 1 & 1 & & & 12 & 6 & 80 \\
\hline humerus & & 1 & 5 & 5 & 8 & 8 & 13 & 15 & 4 & 7 & 5 & & 15 & 7.5 & 100 \\
\hline radius & 9 & 9 & 3 & 4 & 13 & 4 & 5 & 4 & 6 & 7 & & & 13 & 6.5 & 87 \\
\hline ulna & 1 & 5 & 12 & 8 & 9 & 4 & 2 & 2 & & 1 & & & 12 & 6 & 80 \\
\hline metacarpal & 10 & 12 & 11 & 11 & 11 & 12 & 14 & 15 & & & & & 15 & 7.5 & 100 \\
\hline innominate & 1 & 3 & 4 & & 5 & 5 & 5 & 4 & & 3 & 1 & 2 & 5 & 2.5 & 33 \\
\hline femur & 3 & 4 & 4 & 4 & 5 & 4 & 2 & 2 & & 2 & 1 & & 5 & 2.5 & 33 \\
\hline tibia & 1 & 1 & 1 & 2 & 4 & 2 & 3 & 1 & 1 & 4 & & & 4 & 2 & 27 \\
\hline calcaneus & 1 & 4 & 4 & 4 & 4 & & & & & & & & 4 & 2 & 27 \\
\hline astragalus & 6 & 6 & 6 & 6 & & & & & & & & & 6 & 3 & 40 \\
\hline metatarsal & 7 & 7 & 4 & 3 & 11 & 13 & 14 & 13 & & & & & 14 & 7 & 93 \\
\hline phalanx I & 8.5 & 10.5 & 10 & & & & & & & & & & 10.5 & 1.3 & 18 \\
\hline phalanx II & 6.5 & 7 & 7.5 & & & & & & & & & & 7.5 & 0.9 & 13 \\
\hline phalanx III & 2 & 2 & & & & & & & & & & & 2 & 0.25 & 3 \\
\hline
\end{tabular}

elements. The overall patterning that exists among the cattle skeletal elements is a clear underrepresentation of the posterior half of the carcass, with the exception of the metatarsal. The forequarters and mandible are abundant relative to the hindquarters. In fact, the elements of the hindlimb are fairly evenly distributed (Shannon's $e=0.930$ ), and those of the forelimb, more so (Shannon's $e=0.997)$. An explanation of the anomalous abundance of the metatarsal relative to other elements of the hindquarter may reside in its utility in bone-tool manufacture.

Several factors were considered in order to account for the observed pattern. The question of whether or not parts from the left or right sides of the cattle carcass were preferentially selected was assessed by comparing the proportions of left- and right-side elements. This theory may be dismissed, as a chi-square test based on the elements listed in Table 3 (except for the phalanges) indicates that the difference of proportions between left- and right-side skeletal elements is not very significant $\left(\chi^{2}=11.04\right.$, $0.50>\mathrm{p}>0.20$ ).

It is also possible that the skeletal-part frequencies of cattle remains agree with a utilitarian model of carcass exploitation. The Modified General Utility Index (MGUI) measures the amount of meat, fat, marrow and grease associated with each skeletal part in the skeleton (Binford 1978). MGUI values for domestic cattle obtained from actualistic data are not available. The closest taxon for which such data exist is bison (Bison bison) (Emerson 1990, table 7.4), which is used here to interpret the skeletal-part frequencies of cattle remains. A scattergram of the \%MAU val-

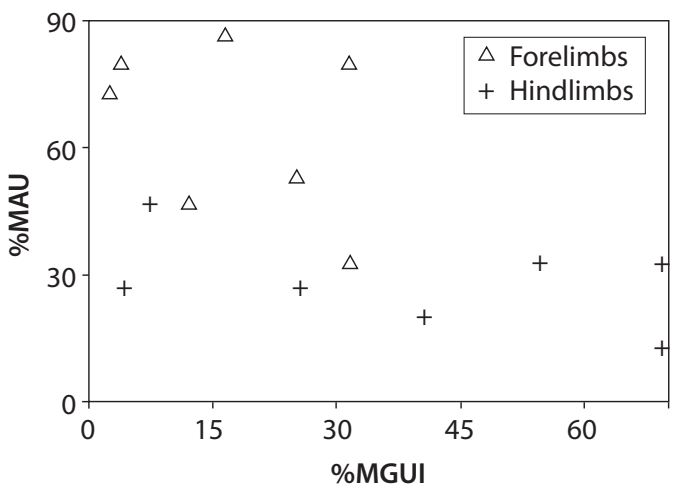

Figure 4. Scattergram showing the relationship between $\% M A U$ and MGUI for cattle remains from HIT $\left(r_{s}=\right.$ $-0.491, p=0.063$ ).

ues for cattle remains from HIT against MGUI values for bison shows a negative correlation coefficient $\left(r_{s}=\right.$ $-0.491, p=0.063$ ) (Fig. 4). This lack of correlation between skeletal-part abundance and food utility indicates that the meat, fat, marrow and grease contained in skeletal portions are not principally responsible for the patterning of cattle remains. While this negative correlation and its 'reverse utility curve' output may in part reflect the omission of long-bone shafts (which was a necessity due to the lack of MGUI values for long-bone shaft portions: Marean \& Kim 1998), food utility does not appear to have been a critical factor. The very clear pattern in the above graph is a separation of forelimb and hindlimb remains with respect to $\% \mathrm{MAU}$, which is expected given that a variation on these data are similarly expressed in Figure 3. 


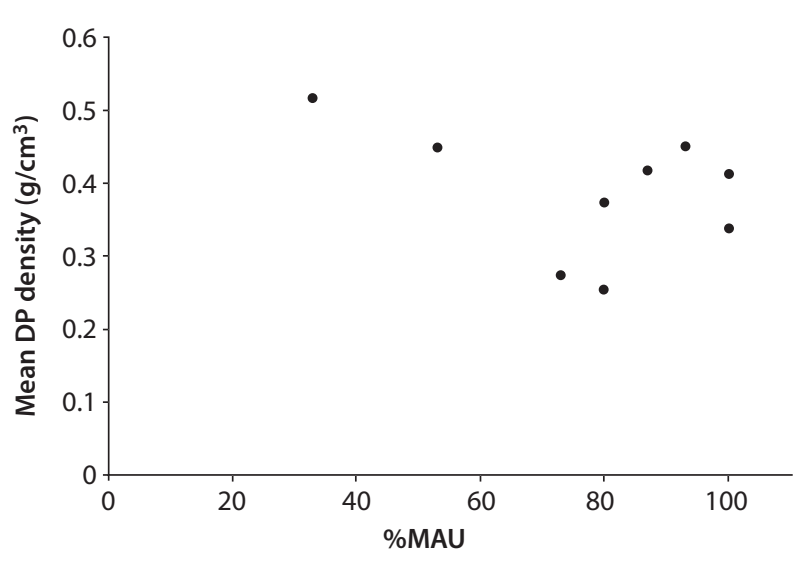

Figure 5. Correlation between $\% M A U$ for cattle and Symmons' bone density (2005, table 3) $\left(r_{s}=0.280, p=\right.$ 0.110).

The correlation coefficient of cattle \%MAU against bone-mineral density, as measured by Symmons (2005), is weak and not significant $\left(r_{s}=0.280\right.$, $p=0.110)$. The marginally positive trend of the data reflects the independence of skeletal part frequency and bone density (Fig. 5). Thus, density-mediated attrition does not appear to be the leading contributor to the formation of the cattle bone assemblage.

This emphasis on the anterior half of the cattle carcass is not a product of density-mediated attrition, nor can it be explained by the relatively high rate of fragmentation incurred by cattle remains as neither of these taphonomic conditions privilege one half of the carcass over the other. Rather, this pattern is best explained by a cultural preference for the anterior half of the cattle carcass. One possibility is that forelimb parts were consumed in the excavated areas of the site with most of the hindlimb parts consumed in an unexcavated area of the site. However, this suggestion does not appear to be the case, as small quantities of hindlimb skeletal parts were found widely dispersed across the site. Another possibility is that, while some beef was acquired in the form of whole carcasses, additional beef from the forequarter arrived at HIT in butchered sections. Yet another possibility is that forelimbs were locally consumed while hindlimbs were involved in exchanges with neighbouring communities or pastoralists.

\section{Regional patterns of cattle skeletal-part representation}

Given the discrepancy between forelimb and hindlimb skeletal-part frequencies identified at HIT, it is imperative to understand if this pattern represents an isolated phenomenon, or if it is also found at other southern Levantine sites of the EBA. To

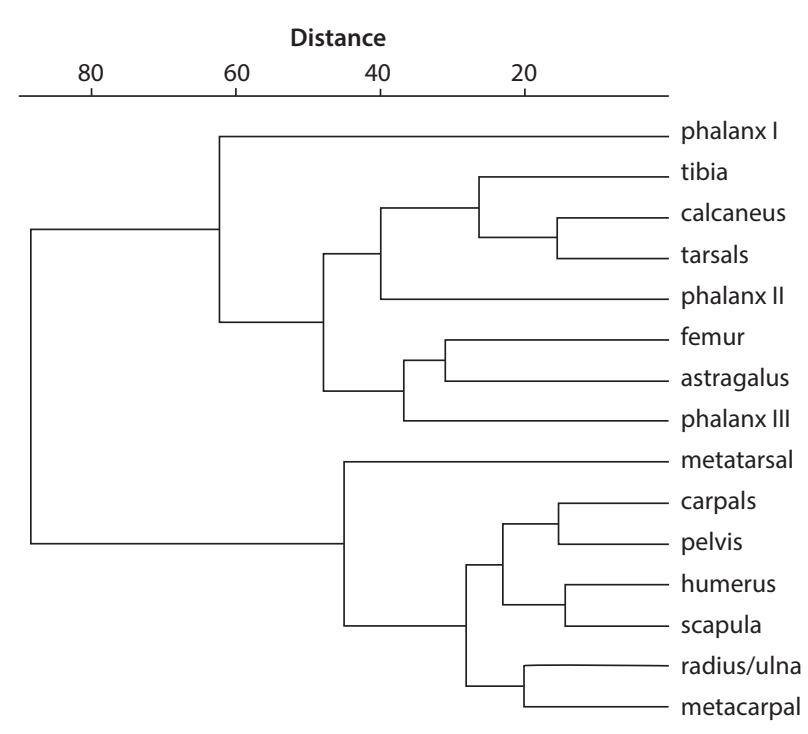

Figure 6. Dendrogram from cluster analysis measuring similarity of 15 skeletal elements for 27 assemblages.

this end, correspondence analysis is used to explore broad-scale regional trends in cattle skeletal-part frequency data, which have been compiled from published and unpublished sources from the late fourth and early third millennium in the southern Levant and Egypt.

Before presenting the results of the correspondence analysis, a dendrogram based on a cluster analysis (unweighted pair-group method, measured in Euclidean distance) of 15 skeletal elements is used to verify the assumption of classification based on anatomical regions (Fig. 6). Indeed, the cluster analysis successfully separates forelimb elements from hindlimb elements, except for the pelvis and metatarsal, which are grouped with elements of the forelimb. Articulating elements within these two groups, such as calcaneus and tarsals, and humerus and scapula, are the more closely related to one another than to other elements. This classification method provides a firm basis on which to apply anatomical region groupings in correspondence analysis on the same data set.

In addition to 25 southern Levantine assemblages, two Egyptian assemblages are included in the correspondence analysis as control samples against which comparisons are made. First, an assemblage from the Old Kingdom-period Pottery Mound area of the Workers' Town at Giza (feature 21557) produced a stark 36:1 ratio of hindlimb to forelimb elements (Redding 2010, 73). While this underrepresentation of forelimb skeletal parts would seem to be at odds with the previously described Egyptian affinity for forelimbs, 


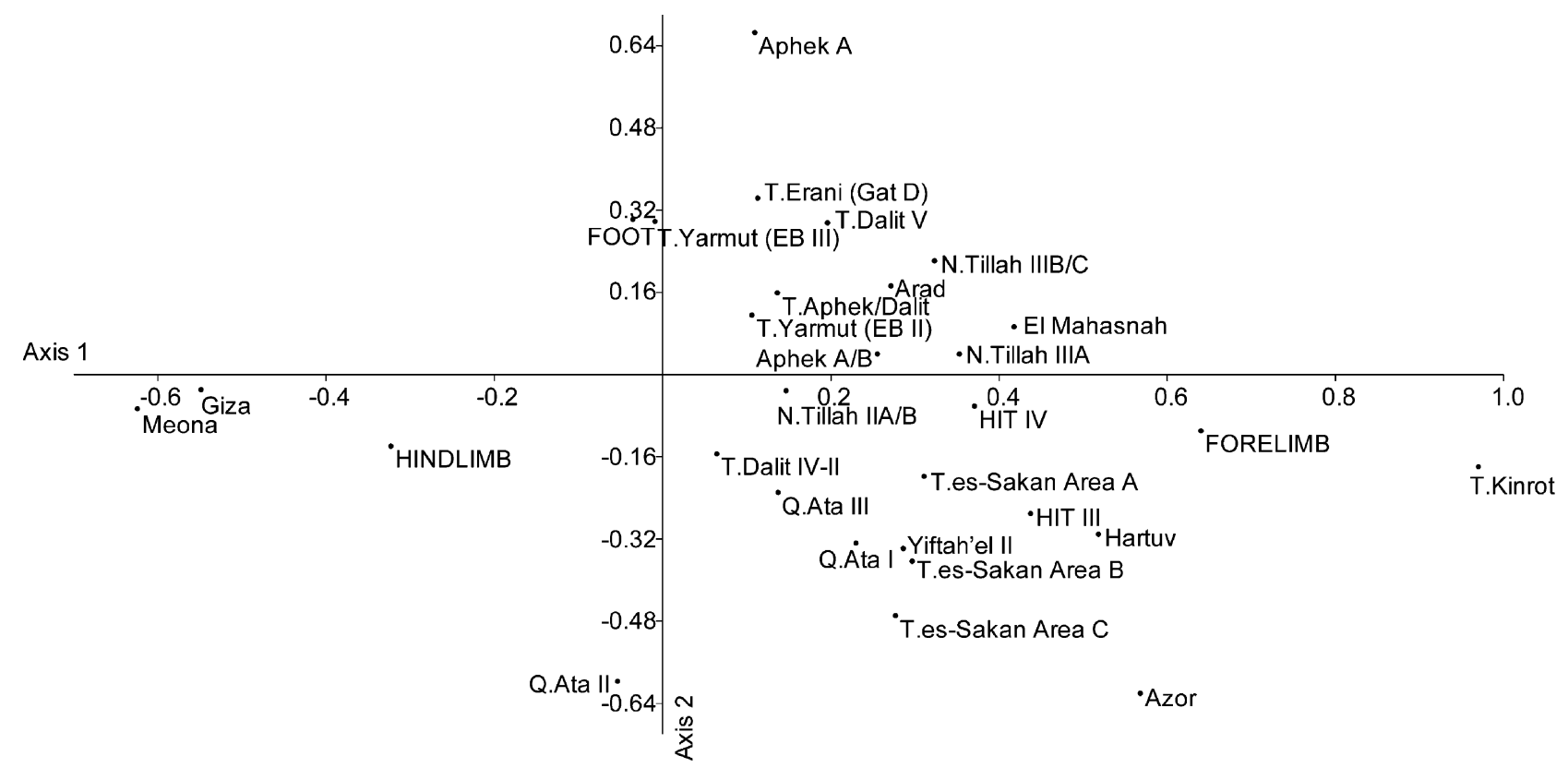

Figure 7. Correspondence analysis of three anatomical regions in 27 assemblages. Data from the following sources: Aphek (Hellwing 2000, table 15.11), Arad (Lernau 1978, table 3), Azor (Horwitz 1999, fig. 21), El Mahasnah (Rossel 2007, table 4.6), Giza (Redding n.d.), Hartuv (Allentuck in press), HIT (Allentuck this study), Me'ona (Horwitz 1996, fig. 2), Nahal Tillah (Kansa in press; Kansa \& Grigson in prep.), Qiryat Ata (Horwitz 2003, table 8.3), Tel Aphek/Dalit (Hellwing $\mathcal{E}$ Gophna 1984, table 4), Tel Dalit (Horwitz et al. 1996, table 2), Tel Erani (Gat D) (Ducos 1968, 114), Tel Kinrot (Hellwing 1988-89, table 5), Tel Yarmut (Davis in press), Tell es-Sakan (Sykes n.d.), Yiftah'el (Horwitz 1997, fig. 17.2).

in fact, the plebeian nature of this particular context fits with the model if the abundance of hindlimbs are considered the unwanted leftovers from elite contexts at Giza. Second, the Predynastic (Naqada Ic-IIc) site of El-Mahâsnah produced an assemblage with five times as many metacarpals as metatarsals (Rossel 2007, 115). This sample is used to represent a skeletal-part pattern typical of high-status Egyptian contexts.

The scattergram displaying the $C A$ results shows 27 assemblages (rows) and three variables (columns) distilled in a single two-dimensional plot (Fig. 7). The first axis, which has the largest eigenvalue of 0.146 , accounts for about 79 per cent of the variation in the data set. The second axis, which is orthogonal to the first axis, has an eigenvalue of 0.039 and accounts for about 21 per cent of the variation in the data set. The first axis shows strong opposition between forelimbs and hindlimbs. At the left side of the diagram, hindlimbs correspond to the EB II site of Meona and the Egyptian site of Giza, both of which have assemblages with high proportions of hindlimb elements relative to forelimb elements. The right side of the diagram shows many more sites that more closely correspond to forelimbs. Most assemblages fall to the positive side of the origin (coordinate 0,0 ), an indication of a positive association of these assemblages with forelimbs. Sites that are in closest proximity to the forelimbs coordinate are $\mathrm{Tel}$ Kinrot, Azor, Hartuv, HIT III, HIT IV, Nahal Tillah IIIA and El-Mahâsnah. If we discount the Egyptian site of El-Mahâsnah and Tel Kinrot, a site that yielded a very small cattle-bone assemblage that likely suffers from sampling bias, the assemblages that most closely correspond with the forelimb region are all from Late EB I (Erani C through 'advanced' sub-phases) strata. Indeed, southern Levantine-Egyptian relations reached their height of intensity during the Late EB I period.

The second axis is rather more ambiguous, but is clearly related to the foot region. Variation along the second axis appears to be a function of the relative proportion of the foot region in each assemblage. For instance, Tel Aphek A, at the upper end of the second axis, is an assemblage dominated by phalanges. By contrast, foot bones are not found at Azor and only one phalange is reported from Qiryat Ata II, and they are accordingly positioned at the lower end of the second axis. The relative proportion of the foot bones to forelimbs and hindlimbs in a given assemblage is likely primarily a function of the coarseness of the chosen recovery technique and inter-assemblage preservation bias, and secondarily a function of cultural selection. 


\section{Discussion}

In light of the CA results, the overrepresentation of cattle forelimbs relative to hindlimbs that are observed at HIT are neither anomalous nor commonplace. The observed pattern is found in several other assemblages, many of which are associated with Late EB I. Indeed, this characteristic of the data has clear resonance in a culture-historical framework in which Egyptiansouthern Levantine relations were never more intense and sustained than in the Late EB I period. Egypt had far-reaching influence in the southern Levant during this brief period, but the material evidence for Egyptian influence is a patchwork across the southern Levant. Sites in the southern reaches of the southern Levant have yielded the largest quantities of Egyptian and Egyptianized artefacts, but only a few sites (e.g. Tell es-Sakan and 'En Besor) have produced high proportions of Egyptian or Egyptianized material culture. Other sites, even those in close proximity to these Egypt-dominated settlements, have produced only a modicum of foreign objects. The patchy distribution of Egyptian material culture in the southern Levant is mirrored by the cattle skeletal-part frequency data of this study. The CA results indicate that sites with the largest Egyptian material assemblages, such as Tell esSakan Area A and Nahal Tillah IIA/B, are not the sites that most closely correspond to the forelimb region. Rather, the sites most closely associated with the forelimb region are those with small Egyptian material assemblages, such as HIT, Nahal Tillah IIIA, Hartuv and Azor. From this, we may conclude that the proportion of cattle forelimbs from a southern Levantine site is not a predictor of the abundance of Egyptian material culture from that site, and vice versa.

\section{Egyptian cattle sacrifice and forelimbs}

The underlying motivation for the selection of cattle forelimbs at HIT and several other Late EB I sites may be understood with analogical reference to practices in Egypt that produced similar patterning in skeletalpart representation. A preference for the cattle forelimb is well known in Egypt from at least the Old Kingdom period. Tomb walls at Saqqara and Giza depict scenes in which slaughtered cattle are forced to the ground with their hindlimbs trussed as the forelimbs are disarticulated with a knife under the scapula (Fig. 8). Ikram (1995) observes that tomb scenes depicting cattle-meat offerings at these sites emphasize forelimbs to the exclusion of hindlimbs. Thus, in this context of elite consumption hindlimbs may be regarded as unwanted leftovers from temple sacrifices.

Styles of animal slaughter and carcass portioning are deliberate acts conceived from specific cultural preferences. Cattle forelimbs as desired elite food offerings in the Old Kingdom period is well attested, but evidence for their prominence in the Predynastic period is emerging. In addition to the previously mentioned scenes of forelimb disarticulation, tombs also show processions of people carrying intact cattle forelimbs and other food as prestation for the offering table of their king (e.g. Junker 1938, fig. 46; Quibell et al. 1898, pl. 38; Simpson 1980, fig. 32). According to Ikram $(1995,116)$, the right foreleg was the first carcass part to be removed following slaughter. This leg was used as a pump handle to expel blood from the body. Next, the head was fully severed from the carcass. Numerous Old Kingdom butchery scenes make these initial steps clear. The remainder of the Egyptian butchery sequence is ambiguous.

Cattle forelimbs were also used as ritual equipment in Egyptian revivification ceremonies known as Opening of the Mouth (Blackman 1924; Roth 1992). Egyptians practised the Opening of the Mouth on human corpses or statues in a ritualized effort to bring movement and power to the deceased or his effigy in the afterlife. The revivification ceremony was enacted by touching ritual objects, usually an adze and the severed forelimb of a bull, to the lips of the subject. In cases for which the bull forelimb was used, the Opening of the Mouth ceremony was immediately preceded by the ritual slaughter of a bull and the amputation of its forelimb. Egyptians regarded the forelimb as an object imbued with $k a$ or animating force for reasons that are not entirely clear.

One theory for the association of the cattle forelimb with a life-giving force is based on empirical observations of post-mortem muscle contractions (Gordon \& Schwabe 2004). Gordon and Schwabe (2004, 80-81) describe their simulation experiment of severing the forelimb from the carcass of a freshly slaughtered bull. They observed muscle contractions that persisted for 15-20 minutes following the amputation. They also found that stabbing or striking a muscle at the elbow or shoulder joints mechanically induced twitching once these muscles stopped contracting naturally. Mechanical stimulation on the severed forelimb was repeated at regular intervals in the hours after the animal's death. The strength of the muscle responses diminished over time, but muscle contractions were elicited for up to two hours after the limb was amputated. ${ }^{2}$ These observations led Gordon and Schwabe to the premise that Egyptian priests would have observed the same sort of involuntary and mechanically induced muscular responses on detached cattle forelimbs. Their argument follows that the observed natural and mechanically stimulated muscle twitches would have inspired the belief that the 


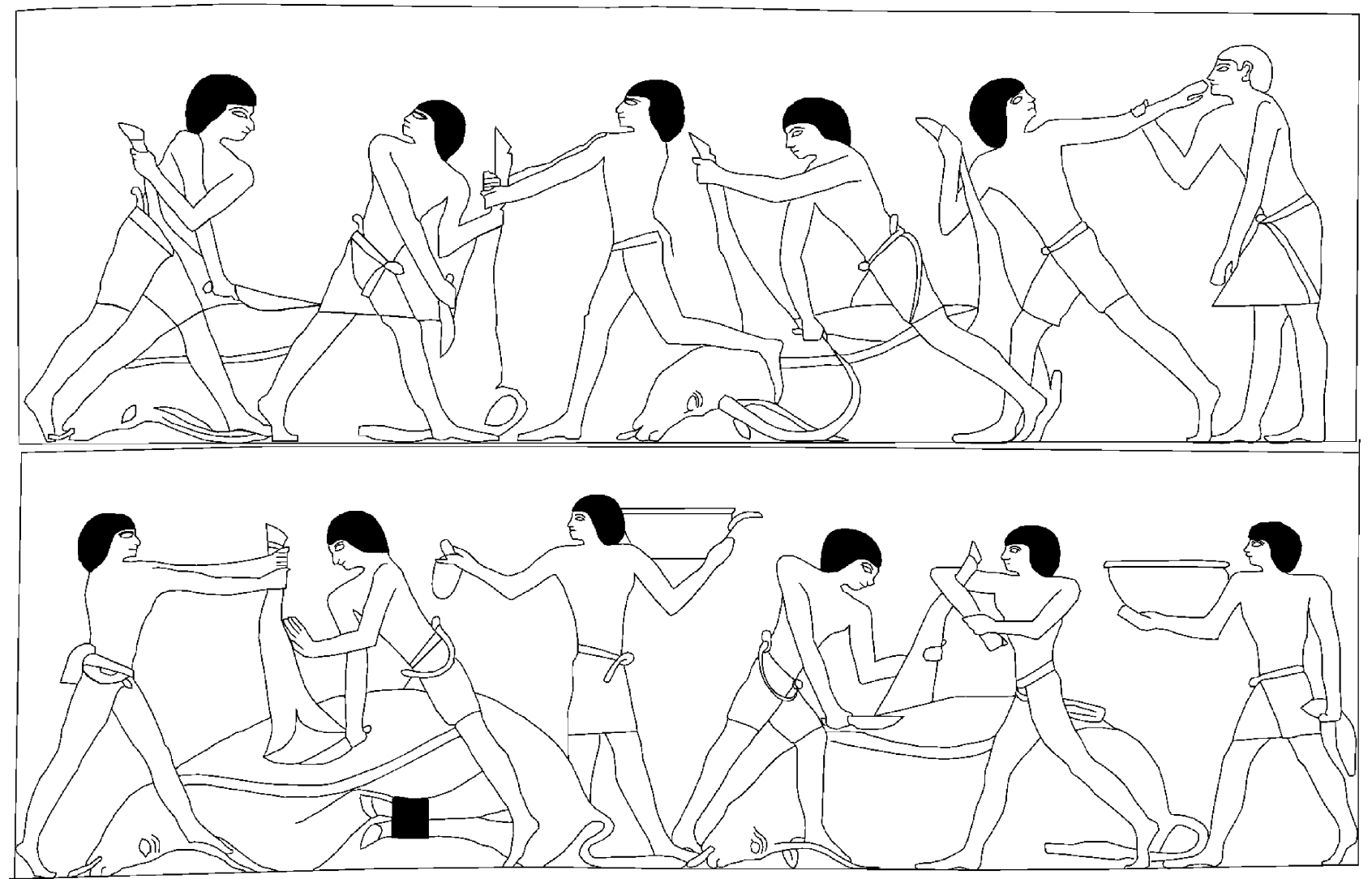

Figure 8. Slaughtering scene from the Tomb of Ptah-Hetep at Saqqara. (Redrawn from Quibell et al. 1898, pl. XXXVI by Kristen Dela Cruz.)

cattle forelimb was an object imbued with an animating force and, moreover, provided a magical source of life-giving power that was transferrable to the deceased in the Opening of the Mouth ceremony.

Others have employed a celestial theory to rationalize the ancient Egyptian attribution of animating force to the cattle forelimb. Wainwright $(1932,11)$ originally proposed that Egyptians imagined an adze or a bull's forelimb in the Ursa major constellation (or more specifically in the Big Dipper asterism). This connection was bolstered by Roth $(1993,70)$, whose reading of the Pyramid Texts of Mernere, found that the adze and forelimb were added to the Opening of the Mouth ceremonial equipment at the same time in the Old Kingdom (Dynasty 6). In fact, Roth (1993, 62-3) has argued convincingly that the antiquity of the Opening of the Mouth ritual should be extended to the Late Predynastic period (Naqada II period), which is coeval with Early EB I in the southern Levantine chronology.

If forelimbs were reserved for elite temple consumption, then to what use were the hindlimbs put? Redding's (2010) analysis of fauna from the Pottery Mound area of the Workers' Town at Giza provides a clear answer to this problem. This work shows that the unused hindlimb portions from the temple may be found in great abundance in the faunal assemblage from the Pottery Mound in the Workers' Town where the hindlimb to forelimb ratio is $36: 1$. The overrepresentation of hindlimb elements in the Workers' Town assemblage, contrasted with the elite affinity for cattle forelimbs known from temple slaughter and offering scenes, indicates that status was reproduced through access to and consumption of a formally divided cattle carcass.

\section{The integrationist nature of the Levantine-Egyptian relations}

The Old Kingdom examples are divided from the Late EB I Levantine context by at least four hundred years, which makes analogical connections between the source and subject tenuous in principle. However, this analogy is strengthened because the association of cattle legs with status in Egypt appears to date at least to the Predynastic period. Legs of chairs and beds shaped as cattle legs found in Naqada III royal tombs at Abydos and in elite tombs at Hierakonpolis and Naqada, among other sites, suggest that cattle legs symbolized power and authority (Hendrickx 
2002, 281-2). While bull sacrifice is well-attested on the walls of Old Kingdom tombs, clear evidence of this practice one thousand years earlier in Naqada IIc is found in the wall painting of Tomb 100 at Hierakonpolis. This scene depicts a display of dominance in which a man slaughters a bull with distinctively trussed feet (Quibell \& Green 1902, pl. LXXV).

Considering the direct contact that occurred between contemporaries living in Egypt and the southern Levant during late fourth and early third millennia, it is conceivable that Levantine people were aware that Egyptians associated cattle slaughter and cattle legs with status. Egyptian knives similar to those depicted in Old Kingdom butchery scenes are found in low frequencies over disparate parts of the southern Levant, including one specimen from HIT. These Egyptian knives lend circumstantial evidence to the contention that Egyptian methods of slaughter and butchery were practised in the southern Levant. Another example comes from Tel Erani where invasive retouch, a purportedly Egyptian technique is found on tools of local raw material (Rosen 1988).

The foremost of Egyptian sites in the southern Levant is Tell es-Sakan on Wadi Ghazzeh (Nahal HaBesor) near the Mediterranean coast. Here, the population appears to have been of Egyptian ethnicity in Late EB I/Dynasty 0 on the basis of its near-homogeneous Egyptian material culture (de Miroschedji et al. 2001). The notion that the indigenous southern Levantines met their Egyptian immigrants with some resistance is evinced by three construction phases of a mud-brick fortification wall. Fortification walls are known from contemporary Late EB I sites in the northern regions of the southern Levant, such as Megiddo, Tell el-Far'ah North and Tell Abu al-Kharaz (Paz 2002), but are unprecedented in Egypt proper at this time (Braun 2011). As impressive and unique as the Late EB I fortification wall is at Tell es-Sakan, it represents rare evidence for adversarial relations between Egypt and the Levant in Late EB I. One of the few other possible signs that southern Levantine people resisted an Egyptian colonial presence has be gleaned from the so-called Picture Pavement excavated from the courtyard of a large Late EB I structure at Megiddo (Yekutieli 2005). In one case, incised images of four headless human figures, which are well-known signs of Egyptian royal power, were subsequently defaced with incised lines and blunt force pecks. Yekutieli (2005) infers that the intention was to erase the original Egyptian motif and in so doing symbolically remove the foreign threat.

However, the bulk of the archaeological evidence from Egypt and the southern Levant does not reflect oppositional relations. Rather, there is a good deal of evidence to suggest integrative social relations. For example, the fortification wall at Tell es-Sakan, rather than understood as physical barrier that separates two communities, may instead demonstrate a transmission of knowledge of Levantine mud-brick technology and wall-building techniques to Egyptian builders (Paz 2002, 254, n.12). A more common form of evidence for knowledge transmission is seen in pottery that bears Levantine and Egyptian stylistic elements. For instance, ledge-handles, which are of Levantine origin, were adapted to vessels made in Egypt. Integration may also be gleaned from 'hybrid' vessels of either Levantine-type forms with Egyptiantype finishes or Egyptian-type forms with Levantinestyle decorations, both of which were identified at Tel Erani (Brandl 1989, 376). Although these 'hybrid' vessel types have been questioned as genuine wares (Braun 2002, 175), they nonetheless demonstrate a mixture of Egyptian and Levantine influences. Similarly, the general class of 'Egyptianized' pottery, vessels formed with Egyptian techniques but produced with Levantine clay, attest to exchange of knowledge and hybridization of material culture. A final illustration of Egyptian-Levantine hybridization may be interpreted from serekhs for which the royal symbol is unknown. A serekh is an Egyptian sign incised or painted on a vessel that marks royal ownership. It comprises a decorated panelled rectangle representing a section of the façade of the royal palace. Stylistically similar serekhs incised on jars found at HIT and Palmahim Quarry have never been attributed to a particular Egyptian ruler. While some scholars assume that this unknown sign represents an Egyptian king (Braun et al. 2001, 66-70), it is also possible that local Levantine leaders co-opted serekh iconographical style and rendered their own unique symbol as a means of marking ownership (Kansa et al. 2006, 78).

\section{Appropriation and indigenization}

Inferences of Egyptian-Levantine hybridity with respect to cattle forelimbs are not out of step with other lines of evidence from the late fourth/early third millennia вс. Indeed, the notion that cattle forelimb butchery and consumption practices shifted in response to Egyptian influence at this time is in agreement with the examples drawn from pottery, lithic, architectural and glyptic evidence in the preceding paragraphs. These examples of imitation and hybridity underscore the point that the cattle forelimbs are not exceptional but rather are in agreement with other lines of evidence.

An assertion that the denizens of HIT displayed their status through the consumption of cattle 
forelimbs would be a contravention of an archaeological record that does not show strong evidence of status markers in Late EB I. Rather, in keeping with the material record of the southern Levant, I suggest that Late EB I communities adopted the Egyptian preference for cattle forelimbs, but translated the meanings of cattle forelimbs to make sense in the local context. Thus, while Egyptians clearly accorded high status to cattle forelimbs, their Levantine contemporaries, who did not have materially inscribed social rankings, defined cattle forelimbs according to their own values that were likely unrelated to status. The southern Levant during the EBA presents scant evidence for status distinctions and did not consolidate political power during the period under study. EBA mortuary data from large cemeteries at Jericho and Bâb edh-Dhrâ do not show evidence of elite burials or even marked status differences (Ilan 2002, 96). Furthermore, exotic objects and luxury goods, most of which are derived from Egypt, are rare. Such items appear widely dispersed in small numbers throughout the southern Levant and have not shown discrete spatial patterning indicative of wealth disparity.

The material record of the EBA suggests that social identity was more likely formed along two fundamental lines: kinship affiliation, which is made clear by large cemeteries divided along networks of kinship (Chesson 1999; Harrison 2001); and local or regional economic relations, which are apparent from the circulation of locally sourced and produced goods within regional exchange networks (Milevski 2011). Kinship and local exchange, rather than status, emerge as salient dimensions that most likely contributed to the formation and expression of social identity in the southern Levantine EBA. The evidence at hand has clear resonance in the meat-sharing practices known from ethnographic research on Turkana pastoralists of Kenya (Lokuruka 2006). The Turkana have strict rules that govern the apportionment of an animal carcass. These rules are based on seniority, age, gender and the recipient's family relation to the donor. For instance, when a woman shares meat with other women in the homestead, the right forelimb is given to the first wife of the male head of the family (Lokuruka 2006, table 1). This and other such rules of meat distribution create obligations of reciprocity and reinforce social bonds and distances between the donor and recipients. The rules that mediate carcass-part provisioning decisions for the Turkana are constructed and institutionalized through a particular history. The conditions that led to distinct treatments of cattle forelimbs and hindlimbs in the southern Levantine EBA were most certainly distinct, a product of historically particular contingencies.
The argument that I have advanced to account for overrepresentations of cattle forelimbs at HIT and several other Late EB I sites is compatible with Dietler's (2007) concept of selective incorporation and indigenization of foreign foods. This process at once adopts certain foods, food practices and tastes, and rejects or ignores others (Dietler 2007, 224). While foreign foods may be emulated faithfully as objects, the exchange and consumption practices of foreign foods are imbued with meanings that accord with a local cultural logic. This theory of appropriation and indigenization of a foreign food accords with Stein's assertion that when a community appropriates objects from another society through exchange or emulation, the borrowers transform meanings of these things so that they make sense in the local cultural context (Stein 2002, 907). This statement is in line with Kopytoff's biographical approach to material culture. He argues that ' ... what is significant about the adoption of alien objects - as of alien ideas - is not the fact that they are adopted, but the way they are culturally redefined and put to use' (Kopytoff 1986, 67). This idea in the modern context of hybridity in transnational exchange has been expressed ardently by Hannerz (1989, 72), who contends that meanings of things may be translated when the flow of communication is asymmetrical, information travels over long distances, and local cultural contexts are shaped by different historical trajectories. In such cases, appropriated material culture is given meaning that makes sense according to the local context.

\section{Conclusion}

This article has presented an approach to interpreting anomalous skeletal-part patterning in zooarchaeological assemblages. While the implications of identifying such patterns may span subsistence, political, religious, economic and other cultural spheres, unusually high proportions of cattle forelimbs and HIT and several other Late EB I sites in the southern Levant are thought to reflect a food preference inspired by neighbouring Egyptians who had a proclivity for cattle forelimbs.

To distinguish food as object and food as practice is a particularly relevant consideration in the present case. Cattle were not exotic animals in the southern Levant at this time, but rather a familiar livestock species since their domestication in the Pre-Pottery Neolithic. By extension, cattle forelimbs would have been familiar objects in the southern Levant. However, as Levantine people learned of Egyptian values of cattle forelimbs through increasingly frequent direct contact in EB I, local valuations of these formerly 
mundane carcass portions underwent a reorientation. In other words, cattle forelimbs were traditional objects, but novel practices with respect to their exchange and consumption emerged as economic relations with Egypt intensified.

\section{Acknowledgements}

This article grew out of my $\mathrm{PhD}$ dissertation undertaken in the Department of Anthropology at the University of Toronto. The first iteration of this research was presented at the Archaeozoology of Southwest Asia (ASWA) conference in Haifa. I am immensely appreciative to colleagues who generously provided unpublished data: Sarah Whitcher Kansa and Caroline Grigson (Nahal Tillah); Richard Redding (Giza), and Naomi Sykes (Tell es-Sakan). Salima Ikram imparted key insights on Egyptian butchery practices. Dissertation research was funded by the Social Sciences and Humanities Research Council of Canada (SSHRC), University of Toronto, Andrea and Charles Bronfman Student Award in Israeli Studies, and Canadian Friends of Hebrew University. I particularly thank Eliot Braun and the Israel Antiquities Authority for allowing me to study the faunal collection from HIT. Finally, I am grateful to John Robb and two anonymous reviewers for giving my manuscript careful consideration.

\section{Notes}

1. Data published maximally as skeletal-region frequencies used in this work are from the following sites/assemblages: Azor (Horwitz 1999), Meona (Horwitz 1996), Qiryat Ata (I, II) (Horwitz 2003), Tel Dalit (IV-II, V) (Horwitz et al. 1996), and Yiftah'el (Horwitz 1997).

2. After a muscle is removed, enzymes may continue to produce adenosine triphosphate (ATP) as long as there is glycogen in the tissue. When glycogen is depleted and ATP to support muscle contraction cannot be produced, the contractile proteins in the muscle fibres become bonded to each other, which signals the onset of rigor mortis (Gordon \& Schwabe 2004, 92).

$$
\begin{array}{r}
\text { Adam Allentuck } \\
\text { Institute of Archaeology } \\
\text { University College London } \\
\text { 31-34 Gordon Square } \\
\text { London } \\
\text { WC1H OPY } \\
\text { UK } \\
\text { Email: a.allentuck@ucl.ac.uk }
\end{array}
$$

\section{References}

Allentuck, A., 2013. Human-Livestock Relations in the Early Bronze Age of the Southern Levant. Unpublished PhD dissertation, University of Toronto.
Allentuck, A., in press. Early Bronze I faunal remains from Hartuv, in Noah's Ark: the Archaeozoology of the Holy Land, eds. G. Bar-Oz. \& L.K. Horwitz. Jerusalem: Israel Antiquities Authority.

Baines, J. \& N. Yoffee, 1998. Order, legitimacy, and wealth in ancient Egypt and Mesopotamia, in Archaic States, eds. G.M. Feinman \& J. Marcus. Santa Fe (NM): School of American Research Press, 199260.

Baxter, M.J. \& H.E.M. Cool, 2010. Correspondence analysis in $\mathrm{R}$ for archaeologists: an educational account. Archeologia e Calcolatori 21, 211-28.

Binford, L.R., 1978. Nunamiut Ethnoarchaeology. New York (NY): Academic Press.

Blackman, A.M., 1924. The rite of opening the mouth in ancient Egypt and Babylonia. The Journal of Egyptian Archaeology 10, 47-59.

Bølviken, E., E. Helskog, K. Helskog, I.M. Holm-Olsen, L. Solheim \& R. Bertelsen, 1982. Correspondence analysis: an alternative to principal components. World Archaeology 14, 41-60.

Brandl, B., 1989. Observations on the Early Bronze Age strata of Tel Erani, in L'urbanisation de la Palestine à l'âge du Bronze ancien, ed. P. de Miroschedji. (British Archaeological Reports, International Series 527.) Oxford: Archaeopress, 357-87.

Brandl, B., 1992. Evidence for Egyptian colonization in the southern coastal plain and lowlands of Canaan during the EB I period, in The Nile Delta in Transition: 3rd Millennium B C., ed. E.C.M. van den Brink. Tel Aviv: van den Brink, 441-77.

Braun, E., 1996. Cultural Diversity and Change in the Early Bronze I of Israel and Jordan: Towards an Understanding of the Chronological Progression and Patterns of Regionalism in Early Bronze I Society. Unpublished PhD dissertation, Tel Aviv University.

Braun, E., 2002. Egypt's first sojourn in Canaan, in Egypt and the Levant: Interrelations from the 4th through the Early 3rd Millennium BCE, eds. E.C.M. van den Brink \& T.E. Levy. London: Leicester University Press, 17389.

Braun, E., 2003. South Levantine encounters with ancient Egypt at the beginning of the third millennium, in $A n-$ cient Perspectives on Egypt, eds. R. Matthews \& C. Roemer. London: UCL Press, 21-37.

Braun, E., 2011. Early interaction between peoples of the Nile valley and the southern Levant, in Before the Pyramids: the Origins of Egyptian Civilization, ed. E. Teeter. Chicago (IL): The Oriental Institute of the University of Chicago, 105-22.

Braun, E. \& E.C.M. van den Brink, 2008. Appraising south Levantine-Egyptian interaction: recent discoveries from Israel and Egypt, in Egypt at its Origins, vol. 2: Proceedings of the International Conference 'Origin of the State, Predynastic and Early Dynastic Egypt', Toulouse (France), 5th-8th September 2005, eds. B. Midant-Reynes \& Y. Tristant. Leuven: Uitgeverij Peeters en Department Oosterse Studies, 64388 . 
Braun, E., E.C.M. van den Brink, R. Gophna \& Y. Goren, 2001. New evidence for Egyptian connections during a late phase of Early Bronze I from the Soreq basin in south-central Israel, in Studies in the Archaeology of Israel and Neighboring Lands in Memory of Douglas L. Esse, ed. S.R. Wolff. Chicago (IL)/Atlanta (GA): The Oriental Institute of the University of Chicago/The American Schools of Oriental Research, 5997.

Chesson, M.S., 1999. Libraries of the Dead: Early Bronze Age charnel houses and social identity at urban Bab edhDhra', Jordan. Journal of Anthropological Archaeology 18, 137-64.

Connan, J., A. Nissenbaum \& D. Dessort, 1992. Molecular archaeology: export of Dead Sea asphalt to Canaan and Egypt in the Chalcolithic-Early Bronze Age (4th3rd millennium вс). Geochimica et Cosmochimica Acta $56,2743-59$.

Davis, S., in press. Were the inhabitants of Tel Yarmouth in Israel, of high status? Some evidence from the Early Bronze Age animal bones, in Noah's Ark: the Archaeozoology of the Holy Land, eds. G. Bar$\mathrm{Oz} \&$ L.K. Horwitz. Jerusalem: Israel Antiquities Authority

Dietler, M., 2007. Culinary encounters: food, identity, and colonialism, in The Archaeology of Food and Identity, ed. K.C. Twiss. Carbondale (IL): Center for Archaeological Investigations, Southern Illinois University Carbondale, 218-42.

Dobney, K. \& K. Rielly, 1988. A method for recording archaeological animal bones: the use of diagnostic zones. Circaea 5, 79-96.

Douglas, M., 2002 [1966]. Purity and Danger: an Analysis of Concepts of Pollution and Taboo. London: Routledge.

Ducos, P., 1968. L'Origine des Animaux Domestiques en Palestine. Bordeaux: Imprimerie Delmas.

Emerson, A.M., 1990. Archaeological Implications of Variability in the Economic Anatomy of Bison bison. Unpublished PhD dissertation, Washington State University.

Fiddes, N., 1991. Meat: a Natural Symbol. London: Routledge.

Gophna, R., 1995. Excavations at 'En Besor. Tel Aviv: Ramot Publishing House, Tel Aviv University.

Gordon, A.H. \& C.W. Schwabe, 2004. The Quick and the Dead: Biomedical Theory in Ancient Egypt. Leiden/Boston (MA): Brill/Styx.

Hannerz, U., 1989. Notes on the global ecumene. Public Culture 1, 66-75.

Harrison, T.P., 1993. Economics with an entrepreneurial spirit: Early Bronze trade with late Predynastic Egypt. Biblical Archaeologist 56, 81-93.

Harrison, T.P., 2001. Early Bronze social organization as reflected in burial patterns from the southern Levant, in Studies in the Archaeology of Israel and Neighboring Lands in Memory of Douglas L. Esse, ed. S.R. Wolff. Chicago (IL)/Atlanta (GA): The Oriental Institute of the University of Chicago/The American Schools of Oriental Research, 215-36.
Hellwing, S., 1988-89. Faunal remains from the Early Bronze and Late Bronze Ages Tel Kinrot. Tel Aviv 15-16, 21320.

Hellwing, S., 2000. Faunal remains, in Aphek-Antipatris I: Excavation of Areas A and B. The 1972-76 Seasons, ed. M. Kochavi. Tel Aviv: Emery and Claire Yass Publications in Archaeology, 293-314.

Hellwing, S. \& R. Gophna, 1984. The animal remains from the Early and Middle Bronze Ages at Tel Aphek and Tel Dalit: a comparative study. Tel Aviv 11, 4859.

Hendrickx, S., 2002. Bovines in Egyptian Predynastic and Early Dynastic iconography, in Droughts, Food and Culture: Ecological Change and Food Security in Africa's Later Prehistory, ed. F.A. Hassan. New York (NY): Kluwer, 275-319.

Horwitz, L.K., 1996. The faunal remains from Me'ona. 'Atiqot 28, 37-9.

Horwitz, L.K., 1997. Faunal remains, in Yiftah'el : Salvage and Rescue Excavations at a Prehistoric Village in the Lower Galilee, Israel, ed. E. Braun. Jerusalem: Israel Antiquities Authority, 155-72.

Horwitz, L.K., 1999. The fauna, in Salvage Excavations at the Early Bronze Age IA Settlement of Azor, eds. A. Golani \& E.C.M. van den Brink. 'Atiqot 38, 33-9.

Horwitz, L.K., 2003. Early Bronze Age animal exploitation at Qiryat Ata, in Salvage Excavations at the Early Bronze Age Site of Qiryat Ata, ed. A. Golani. Jerusalem: Israel Antiquities Authority, 225-41.

Horwitz, L.K. \& E. Tchernov, 1989. Animal exploitation in the Early Bronze Age of the southern Levant: an overview, in L'urbanisation de la Palestine à l'âge du Bronze ancien, ed. P. de Miroschedji. (British Archaeological Reports, International Series 527.) Oxford: Archaeopress, 279-96.

Horwitz, L.K., S. Hellwing \& E. Tchernov, 1996. Patterns of animal exploitation at Early Bronze Age Tel Dalit, in Excavations at Tel Dalit: an Early Bronze Age Walled Town in Central Israel, ed. R. Gophna. Tel Aviv: Ramot Publishing, Tel Aviv University, 193-216.

Ikram, S., 1995. Choice Cuts: Meat Production in Ancient Egypt. Leuven: Uitgeverij Peeters en Department Oosterse Studies.

Ilan, D., 2002. Mortuary practices in Early Bronze Age Canaan. Near Eastern Archaeology 65, 92104.

Junker, H., 1938. Gîza III. Die Mastabas der vorgeschrittenen V. Dynastie auf dem Westfriedhof. Vienna: Hölder-PichlerTempsky A.G.

Kansa, E.C., 2001. Smitten by Narmer: Ethnicity, Economy and Trade in the 4th Millennium BCE Egyptian Presence in the Southern Levant. Unpublished PhD dissertation, Harvard University.

Kansa, E.C., S.W. Kansa \& T.E. Levy, 2006. Eat like an Egyptian? A contextual approach to an Early Bronze I 'Egyptian colony' in the southern Levant, in Integrating Zooarchaeology, ed. M. Maltby. Oxford: Oxbow Books, 76-91. 
Kansa, S.W., in press. Animal exploitation at the Halif Terrace during the Early Bronze IA and IB (c. 3600-3000 BCE), in Noah's Ark: the Archaeozoology of the Holy Land, eds. G. Bar-Oz \& L.K. Horwitz. Jerusalem: Israel Antiquities Authority.

Kansa, S.W. \& C. Grigson, in prep. Zooarchaeology of Early Bronze Age Nahal Tillah. Open Context. doi:10.6078/M7QN64NW.

Kemp, B.J., 2006. Ancient Egypt: Anatomy of a Civilization. 2nd edition. London: Routledge.

Kopytoff, I., 1986. The cultural biography of things: commoditization as process, in The Social Life of Things: Commodities in Cultural Perspective, ed. A. Appadurai. Cambridge: Cambridge University Press, 6491.

Lernau, H., 1978. Faunal remains, strata III-I, in Early Arad: the Chalcolithic Settlement and Early Bronze Age City, ed. R. Amiran. Jerusalem: Israel Exploration Society, 83-113.

Levy, T.E., D. Alon, P. Smith et al., 1997. Egyptian-Canaanite interaction at Nahal Tillah, Israel (ca. 4500-3000 BCE): an interim report on the 1994-1995 excavations. Bulletin of the American Schools of Oriental Research 307, $1-51$.

Lokuruka, M.N.I., 2006. Meat is the meal and status is by meat: recognition of rank, wealth, and respect through meat in Turkana culture. Food \& Foodways 14, 201-29.

Lyman, R.L., 2008. Quantitative Paleozoology. Cambridge: Cambridge University Press.

Marean, C.W. \& S.Y. Kim, 1998. Mousterian large-mammal remains from Kobeh Cave: behavioral implications for Neanderthals and early modern humans. Current Anthropology 39, S79-113.

McGovern, P.E., U. Hartung, V.R. Badler, D.L. Glusker \& L.J. Exner, 1997. The beginnings of winemaking and viniculture in the ancient Near East and Egypt. Expedition 39, 3-21.

Milevski, I., 2011. Early Bronze Age Goods Exchange in the Southern Levant: a Marxist Perspective. London: Equinox.

de Miroschedji, P., 2002. The socio-political dynamics of Egyptian-Canaanite interaction in the Early Bronze Age, in Egypt and the Levant: Interrelations from the 4th through the Early 3rd Millennium BCE, eds. E.C.M. van den Brink \& T.E. Levy. London: Leicester University Press, 39-57.

de Miroschedji, P., M. Sadeq, D. Faltings et al., 2001. Les fouilles de Tell es-Sakan (Gaza): nouvelles donnés sur les contacts Égypto-Cananéens aux IV $^{\mathrm{e}}-\mathrm{III}^{\mathrm{e}}$ millénaires. Paléorient 27, 75-104.

Paz, Y., 2002. Fortified settlements of the EB IB and the emergence of the first urban system. Tel Aviv 29, 23861.

Pickering, T.R., C.W. Marean \& M. Domínguez-Rodrigo, 2003. Importance of limb bone shaft fragments in zooarchaeology: a response to 'On in situ attrition and vertebrate body part profiles' (2002), by M.C. Stiner. Journal of Archaeological Science 30, 1469-82.
Quibell, J.E. \& F.W. Green, 1902. Hierakonpolis, part II. London: Bernard Quaritch.

Quibell, J.E., R.F.E. Paget \& A.A. Pirie, 1898. The Ramesseum and the Tomb of Ptah-Hetep. London: Bernard Quaritch.

Redding, R., 2010. Status and diet at the Workers' Town, Giza, Egypt, in Anthropological Approaches to Zooarchaeology: Complexity, Colonialism, and Animal Transformations, eds. D. Campana, P. Crabtree, S.D. deFrance, J. Lev-Tov \& A. Choyke. Oxford: Oxbow Books, 6575.

Redding, R., n.d. Unpublished data from Workers' Town at Giza.

Regev, J., P. de Miroschedji, R. Greenberg, E. Braun, Z. Greenhut \& E. Boaretto, 2012. Chronology of the Early Bronze Age in the southern Levant: new analysis for a high chronology. Radiocarbon 54, 525-66.

Rosen, S.A., 1988. A preliminary note on the Egyptian component of the chipped stone assemblage from Tel 'Erani. Israel Exploration Journal 38, 105-16.

Rossel, S., 2007. The Development of Productive Subsistence Economies in the Nile Valley: Zooarchaeological Analysis at El-Mahâsna and South Abydos, Upper Egypt. Unpublished PhD dissertation, Harvard University.

Roth, A.M., 1992. The psš-kf and the 'Opening of the Mouth' ceremony: a ritual of birth and rebirth. The Journal of Egyptian Archaeology 78, 113-47.

Roth, A.M., 1993. Fingers, stars, and the 'Opening of the Mouth': the nature and function of the ntrwj-blades. The Journal of Egyptian Archaeology 79, 57-79.

Shennan, S., 1988. Quantifying Archaeology. Edinburgh/San Diego (CA): Edinburgh University Press/Academic Press.

Simpson, W.K., 1980. Mastabas of the Western Cemetery: part I. volume 4. Boston (MA): Museum of Fine Arts.

Stager, L.E., 2001. Port power in the Early and the Middle Bronze Age: the organization of maritime trade and hinterland production, in Studies in the Archaeology of Israel and Neighboring Lands in Memory of Douglas L. Esse, ed. S.R. Wolff. Chicago (IL)/Atlanta (GA): The Oriental Institute of the University of Chicago/The American Schools of Oriental Research, 625-38.

Stein, G.J., 2002. From passive periphery to active agents: emerging perspectives in the archaeology of interregional interaction. American Anthropologist 104, 90316.

Stiner, M.C., 2002. On in situ attrition and vertebrate body part profiles. Journal of Archaeological Science 29, 97991.

Sykes, N., n.d. Unpublished data from Tell es-Sakan.

Symmons, R., 2005. New density data for unfused and fused sheep bones, and a preliminary discussion on the modelling of taphonomic bias in archaeofaunal age profiles. Journal of Archaeological Science 32, 1691-8.

Ter Braak, C.J.F., 1986. Canonical correspondence analysis: a new eigenvector technique for multivariate direct gradient analysis. Ecology 67, 1167-79. 
Twiss, K.C., 2007. We are what we eat, in The Archaeology of Food and Identity, ed. K.C. Twiss. Carbondale (IL): Center for Archaeological Investigations, Southern Illinois University Carbondale, 115.

Wainwright, G.A., 1932. Iron in Egypt. The Journal of Egyptian Archaeology 18, 3-15.

Watson, J.P.N., 1979. The estimation of the relative frequencies of mammalian species: Khirokitia 1972. Journal of Archaeological Science 6, 127-37.

Yekutieli, Y., 2005. Project gallery: deconstruction and reconstruction of fourth millennium BC icono- clastic graffiti. Antiquity 79 http://antiquity.ac.uk/ projgall/yekutieli305/ [Accessed 13 October 2014.]

\section{Author biography}

Adam Allentuck is a Social Sciences and Humanities Research Council of Canada (SSHRC) Postdoctoral Fellow in the Institute of Archaeology at University College London. His current research focus concerns zooarchaeological investigations at the Epipalaeolithic mega-site of Kharaneh IV in the eastern desert of Jordan. 